Al Maal : Journal of Islamic Economics and Banking

http://jurnal.umt.ac.id/index.php/jieb

E-ISSN : $2580-3816$

Vol : Vol 2 No. 1 Bulan Januari Tahun 2021

Hlm : $143-159$

DOI $\quad$ : $10.31000 /$ almaal.v2i2.3201

\title{
Analisis Pengaruh Perilaku Konsumtif, Motivasi, Kelompok Referensi, Kualitas Layanan Terhadap Keputusan Menabung
}

\author{
Melina Agustina Rahayu1, ${ }^{1, *}$ Mustika Widowati², Jati Handayani ${ }^{3}$ \\ 1,2,3 Program Studi Perbankan Syariah, Politeknik Negeri Semarang, Semarang, Indonesia \\ *email.melinaagustinaa3@gmail.com
}

\begin{abstract}
This study analyze and obtain empirical evidence about the effect of Consumptive Behavior, Motivation, Reference Group and Service Quality on the Decisions of Saving at PT Bank Tabungan Negara (BTN) Branch Office Sharia Semarang either simultaneously or partially. The population of this research is the customers of PT Bank Tabungan Negara (BTN) Branch Office Sharia Semarang. Sample technique used is purposive sampling and accidental sampling technique, there are 135 respondents who meet the criteria. The analysis model used in this study is a multiple linier regression analysis model. The analysis technique uses F test, Determination Coefficient Test (R2), and t test which is processed using SPSS 16 program. The results of proving the hypothesis and discussion in this study indicate that (1) Consumptive Behavior, Motivation, Reference Group and Service Quality simultaneously have a significant impact on saving decisions (2) Consumptive Behavior partially has no significant effect on saving decisions. (3) Motivation partially has a significant effect on saving decisions. (4) The reference group partially does not significantly influence on saving decisions. (5) Service quality partially has significant effect on savinng decisions.
\end{abstract}

Keywords: Savings Decision; Consumptive Behavior; Motivation; Reference Group; Service Quality.

\begin{abstract}
ABSTRAK
Penelitian ini menganalisis dan mendapatkan bukti empiris mengenai pengaruh perilaku konsumtif, motivasi, kelompok referensi dan kualitas layanan terhadap keputusan menabung pada PT Bank Tabungan Negara (BTN) Kantor Cabang Syariah Semarang baik secara simultan maupun parsial. Populasi dalam penelitian ini adalah nasabah PT Bank Tabungan Negara (BTN) Kantor Cabang Syariah. Dengan menggunakan teknik pengambilan sampel yaitu purposivesampling dan accidental sampling terdapat 135 responden yang memenuhi kriteria. Model analisis yang digunakan dalam penelitian ini adalah model analisis regresi linier berganda, sedangkan teknik analisis menggunakan Uji $F$, uji Koefisien Determinasi $\left(R^{2}\right)$, Uji $t$ yang diolah menggunakan program SPSS 16. Hasil pembuktian hipotesis dan pembahasan menunjukkan bahwa (1) perilaku konsumtif, motivasi, kelompok referensi dan kualitas layanan secara simultan berpengaruh signifikan terhadap keputusan menabung. (2) Perilaku konsumtif secara parsial tidak berpengaruh signifikan terhadap keputusan menabung. (3) Motivasi secara parsial berpengaruh signifikan terhadap keputusan menabung. (4) Kelompok referensi secara parsial tidak berpengaruh signifikan terhadap keputusan menabung pada. (5) Kualitas layanan secara parsial berpengaruh signifikan terhadap keputusan menabung.
\end{abstract}

Kata kunci: Keputusan Menabung; Perilaku Konsumtif; Motivasi; Kelompok Referensi; Kualitas Layanan. 


\section{Pendahuluan}

Saat ini bisnis jasa berkembang luas, terlebih pada bidang perbankan yang sangat pesat perkembangannya. Kehadiran perbankan yang berbasis syariah juga dapat memenuhi kebutuhan masyarakat yaitu memberikan pelayanan jasa perbankan menggunakan prinsip Islam. Dengan menggunakan produk dari bank syariah merupakan salah satu bentuk atau cara masyarakat ikut berkontribusi untuk memajukan perbankan syariah khususnya di Indonesia.

Menurut hasil sensus penduduk oleh Badan Pusat Statistik menunjukkan bahwa jumlah penduduk beragama Islam di Indonesia sebanyak 207.176.162 jiwa atau 87,18\% penduduk dari total penduduk di Indonesia (www.bps.go.id). Dalam hal ini, besarnya peluang yang ada mampu menjadi kesempatan baik bagi perkembangan industri keuangan syariah sehingga dapat mendorong perekonomian negara. Namun, pada kenyataannya yang terjadi di Indonesia besaran market share perbankan syariah di Indonesia belum menunjukkan peningkatan yang signifikan, yaitu hanya sebesar $6,01 \%$ pada tahun 2019 sedangkan bank konvensional mencapai 93,99\%. Ini membuktikan bahwa perbankan syariah harus memiliki strategi dalam meningkatkan kinerjanya, mampu memahami keinginan pasar, sehingga mampu bersaing dalam penguasaan pangsa pasar. Peningkatan kinerja perbankan syariah ini tidak dapat terlepas dari peran masyarakat dalam menentukan keputusan menjadi nasabah pada bank syariah itu sendiri. Jika jumlah masyarakat yang memutuskan untuk menjadi nasabah meningkat, maka besar kemungkinan untuk dapat meningkatkan pangsa pasar perbankan syariah di Indonesia.

Khususnya di Indonesia yang mayoritas penduduknya adalah muslim sangat menjadi peluang besar bagi para pebisnis dibidang perbankan syariah. Seperti yang kita ketahui bahwa persaingan bisnis terutama dalam bidang perbankan memang sangat ketat. Semua Bank Umum Syariah (BUS), Unit Usaha Syariah (UUS) maupun Bank Pembiayaan Rakyat Syariah (BPRS) berlomba-lomba untuk mencapai target dan salah satunya yaitu dengan meningkatkan penghimpunan Dana Pihak Ketiga (DPK). Dari data yang didapat melalui riset Laporan SPS Otoritas Jasa Keuangan (OJK) Pertumbuhan rekening Dana Pihak Ketiga masih fluktuati hingga tahun 2020 yaitu 0,91\% dibandingkan tahun 2019 sebesar $12,48 \%$.

Kemudian dari Laporan OJK tahun 2019 juga terjadi penurunan pertumbuhan pembiayaan dari tahun 2019 sebesar 8,44\% menjadi -0,59\% di awal tahun 2020. Perubahan yang cukup siginifikan merupakan salah satu hal yang perlu diperhatikan karena dapat memengaruhi perkembangan Dana Pihak Ketiga (DPK) pada Unit Usaha Syariah (UUS) tersebut. Sedangkan, Dana Pihak Ketiga (DPK) merupakan salah satu sumber pendapatan bagi bank. Dengan meningkatnya pertumbuhan Dana Pihak Ketiga (DPK), maka diharapkan tingkat pembiayaan juga semakin tinggi dan pertumbuhan nasabah atau pelanggan semakin tinggi pula. Dengan demikian semakin tinggi profit yang didapat oleh bank.

Pada data market share perbankan syariah disebutkan Unit Usaha Syariah (UUS) berkontribusi sebesar 32,56\%. Hal tersebut menandakan Unit Usaha Syariah (UUS) mampu berkontribusi meningkatkan market share perbankan syariah lebih besar daripada Bank Pembiayaan Rakyat Syariah (BPRS). Dengan data saat ini pada Januari tahun 2020 jumlah Kantor Layanan Syariah dari Unit Usaha Syariah (UUS) di Indonesia sebanyak 2.947 unit kantor layanan. 
PT Bank Tabungan Negara (BTN) Kantor Cabang Syariah merupakan salah satu Unit Usaha Syariah (UUS) dari PT Bank Tabungan Negara Konvensional yang mulai beroperasi tanggal 14 Februari 2005 melalui pembukaan Kantor Cabang Syariah pertama di Jakarta. Semakin berkembangnya PT Bank Tabungan Negara (BTN) Kantor Cabang Syariah menambah Kantor Cabang Syariah di beberapa kota. Salah satunya, yaitu di kota Semarang, Jawa Tengah.

Dengan tugas utama perbankan yaitu melakukan penghimpunan dana dan penyaluran dana, PT Bank Tabungan Negara (BTN) Kantor Cabang Syariah Semarang memiliki salah satu permasalahan yang perlu diperhatikan. Hal tersebut mengenai tingkat pertumbuhan Dana Pihak Ketiga (DPK) dan Aset yang pertumbuhannya belum stabil. Terlebih pada tahun 2019 mengalami penurunan Dana Pihak Ketiga (DPK) sebesar 21.860.438 atau pertumbuhannya turun sebesar $-0,04 \%$ dibandingkan tahun sebelumnya tahun 2018 sebesar 22.342.675 atau 19,13\% pertumbuhannya (Laporan Triwulan IV, 2019).

Adanya penurunan tersebut perlu diperhatikan oleh PT Bank Tabungan Negara (BTN) Kantor Cabang Syariah Semarang karena penurunan aset dan Dana Pihak Ketiga (DPK) akan berdampak pada keberlangsungan usaha. Hal tersebut terjadi salah satunya dimungkinkan karena adanya penurunan tingkat keputusan menabung nasabah yang dipengaruhi oleh beberapa faktor. Dengan demikian berdasarkan fenomena bisnis yang terjadi dan adanya penelitian terdahulu beserta teori yang relevan maka pada penelitian ini bertujuan menganalisis faktor-faktor yang dimungkinkan memengaruhi keputusan menabung nasabah meliputi perilaku konsumtif, motivasi, kelompok referensi dan kualitas layanan.

\section{KAJIAN LITERATUR Keputusan Menabung}

Menurut Kotler dan Keller (2012:188) keputusan pembelian adalah sebuah proses pendekatan penyelesaian masalah yang terdiri dari pengenalan masalah, mencari informasi, beberapa penilaian alternatif, membuat keputusan membeli dan perilaku setelah membeli yang dilalui nasabah. Pengenalan masalah merupakan langkah awal dalam pengambilan keputusan. Pembeli merasakan perbedaan antara keadaan yang sebenarnya dan keadaan yang diidamkannya. Kebutuhan itu bisa timbul oleh rangsangan dari dalam dan luar. Rangsangan tersebut yang dapat membawanya untuk mengenal masalah kebutuhan. Pada tahap ini rangsangan membangkitkan minat pembeli dalam suatu jenis produk. Kemudian,tahap selanjutnya yaitu pencarian informasi, dimana ketika konsumen yang tergerak pada tahap ini dimungkinkan mencari informasi lebih banyak tentang suatu produk. Apabila drive konsumen itu sangat kuat, maka muncul beberapa faktor yang menjadi pertimbangan konsumen untuk memilih satu alternatif dari banyak alternatif yang tersedia. Hal tersebut terjadi pada tahap evaluasi alternatif. Tahap evaluasi membuat para konsumen menyusun daftar peringkat barang untuk menentukan keputusan pembelian. Sehingga, tahap terakhir yaitu tingkah laku setelah pembelian yaitu setelah membeli sebuah produk, konsumen akan merasa puas atau tidak puas. Apabila konsumen merasa puas, besar kemungkinan untuk melakukan pembelian ulang atau secara berkala (Kotler dan Keller, 2012:189).

Maka dari itu, salah satu cara untuk mendapatkan nasabah sebuah bank perlu memahami perilaku calon nasabah dengan baik agar mampu menimbulkan keputusan 
menabung yang nantinya dapat bersaing dengan bank lainnya. Selain itu, informasi suatu bank sangat diperlukan oleh calon nasabah, baik berasal dari bank itu sendiri maupun dari pengalaman oranglain sebelum memutuskan untuk menabung pada suatu bank. Dengan demikian, keputusan menabung merupakan pemilihan atas dasar logika atau pertimbangan di antara beberapa alternatif yang dilakukan secara sadar oleh pihak yang menempatkan dananya ke pihak bank (Maski, 2010).

\section{Perilaku Konsumtif}

Konsumsi merupakan aktivitas manusia yang paling mendasar. Konsumsi dimaknai secara beragam. Menurut Soebiyakto (1988:17) dalam Pratiwi (2015) menjelaskan bahwa konsumsi merupakan suatu pemenuhan kebutuhan yang diperlukan sesuai dengan apa yang dibutuhkan. Perilaku konsumtif didefinisikan sebagai suatu perilaku membeli dan menggunakan barang yang tidak didasarkan pada perimbangan yang rasional dan memiliki kecenderungan untuk mengonsumsi sesuatu tanpa batas dimana individu lebih mementingkan faktor keinginan daripada kebutuhan serta ditandai oleh adanya kehidupan mewah dan berlebihan, penggunaan segala hal yang paling mewah yang memberikan kepuasan dan kenyamanan fisik (Pramudi, 2015).

Keynes dalam Putong (2003:176) menyatakan bahwa ia tidak sependapat dengan kaum klasik yang beranggapan bahwa tingkat tabungan sepenuhnya ditentukan oleh tingkat bunga. Ia berpendapat bahwa besar kecilnya tingkat tabungan juga ditentukan oleh besar kecilnya tingkat pendapatan dan kecenderungan mengonsumsi.

Putong (2003:186) mengatakan bahwa semua pendapatan yang tidak dikonsumsi itu ditabung dan atau dipergunakan untuk investasi. Semakin tinggi konsumsi berarti semakin kecil tabungan dan sebaliknya semakin besar tabungan akan mengurangi tingkat konsumsi (Zainal, 2018: 321). Dalam hal ini berarti penting diperhatikan bahwa perilaku konsumen dalam melakukan konsumsi yang diharapkan juga mampu memenuhi keperluan atau kebutuhan di masa mendatang diantaranya melalui investasi dan tabungan. Keputusan dalam menabung merupakan salah satu hal yang penting diperhatikan dalam manajemen perilaku konsumen, karena mampu menunjang kontribusi lebih besar terhadap bank syariah.

\section{Motivasi}

Menurut Mashlow (1970) dalam Kotler dan Keller (2012:183) Motivasi diartikan sebagai sebuah dorongan yang muncul berasal dari dalam maupun luar diri seseorang yang mengakibatkan seseorangtersebut melakukan suatu tindakan atau berusaha untuk memenuhi keinginannya. Teori hierarki kebutuhan Maslow yang terdiri atas lima kategori yaitu pertama: kebutuhan fisiologis termasuk makanan, udara dan sebagainya, kedua: kebutuhan keamanan seperti keselamatan dan keamanan, ketiga: kebutuhan kebersamaan seperti cinta kasih sayang termasuk kebutuhan akan diterima oleh rekan sebaya, keempat: kebutuhan penghargaan seperti kebutuhan akan citra diri, harga diri serta dihormati oleh orang lain, dan kelima: kebutuhan aktualisasi diri. Hal ini melibatkan seseorang dalam mewujudkan potensi sepenuhnya dan menjadi semua yang mampu dicapainya.

Motivasi merupakan keadaan dalam pribadi seseorang yang mendorong keinginan individu untuk melakukan kegiatan-kegiatan tertentu guna mencapai suatu tujuan. Tiap kegiatan yang dilakukan oleh seseorang didorong oleh suatu kekuatan dalam dirinya, kekuatan itulah yang disebut motif. Oleh sebab itu, kita dapat mengetahui bahwa 
sebenarnya perilaku konsumen dimulai dengan adanya suatu motif atau motivasi (Kristianto, 2011:46).

\section{Kelompok Referensi}

Menurut Kotler dan Keller (2012:175) reference group adalah kelompokkelompok yang mempengaruhi langsung atau tidak langsung sikap dan tingkah laku orang itu. Seseorang atau sekelompok orang yang mempengaruhi perilaku individu secara signifikan seperti artis, atlet, tokoh politik, kelompok musik,dan partai politik. Menurut Pramudi (2015) kelompok acuan adalah individu atau sekelompok orang yang mempengaruhi perilaku seseorang serta memberikan standar dan nilai terhadap perilaku seseorang. Kelompok yang memiliki pengaruh langsung terhadap seseorang dinamakan kelompok keanggotaan.Beberapa kelompok merupakan kelompok primer (primary group) yang berinteraksi dengan orang tersebut secara terus-menerus seperti keluarga, teman, tetangga dan kolega. Sedangkan kelompok sekunder (secondary group) cenderung bersifat lebih resmi dan interaksi semakin jarang, misalnya dalam suatu organisasi.

\section{Kualitas Layanan}

Menurut Othman dan Owen (2001) kualitas pelayanan merupakan perbandingan antara layanan yang diharapkan oleh pelanggan dengan layanan yang diterima. Kualitas pelayanan juga memiliki hubungan yang erat dengan keputusan nasabah menyimpan dananya di bank. Kualitas pelayanan memberikan suatu dorongan kepada nasabah untuk menjalin ikatan yang kuat dengan bank. Dalam jangka panjang, memungkinkan bank untuk memahami dengan seksama harapan nasabah serta kebutuhan mereka (Fahrudin dan Yulianti, 2015).

Othman dan Owen (2001) mengembangkan model pengukuran kualitas jasa untuk mengukur kualitas jasa yang dijalankan menggunakan prinsip syariah khususnya bisnis perbankan syariah. Model ini disebut dengan model CARTER. Model ini mempunyai enam dimensi yaitu Compliance, Assurance, Reliability, Tangibles, Emphaty, dan Responsiveness.

\section{Metode Penelitian}

Desain penelitian ini yaitu penelitian kuantitatif terapan kausalitas. Dengan populasi yaitu nasabah PT Bank Tabungan Negara (BTN) Kantor Cabang Syariah Semarang. Sampel yang digunakan yaitu purposive dan accidental sampling dengan menggunakan Hair, et al., (2010) dalam Sulistyorini (2017). Sedangkan metode pengumpulan data dalam penelitian yaitu kuisioner, wawancara dan studi dokumenter. Data diuji dengan beberapa tahapan seperti uji kualitas data meliputi uji validitas dan reliabilitas, uji normalitas, uji asumsi klasik meliputi uji multikolonieritas dan heteroskedastisitas. Penelian ini menggunakan model analisis regresi linier berganda. Analisis data yang digunakan yaitu Uji Statistik F, Uji Koefisien Determinasi $\left(\mathrm{R}^{2}\right)$ dan Uji Statistik t.

\section{Hasil dan Pembahasan}

Karena data yang digunakan adalah data primer maka untuk menentukan ketepatan model perlu dilakukan pengujian atas beberapa prngujian yaitu Uji Validitas dan Uji Reliabilitas, uji normalitas dan uji asumsi klasik yang digunakan yaitu: Uji Multikolonieritas dan Uji Heteroskedastisitas secara rinci dijelaskan sebagai berikut. 


\section{Uji Validitas}

Uji validitas digunakan untuk mengukur sah atau valid tidaknya suatu kuesioner. Uji signifikansi dilakukan dengan membandingkan nilai rhitung dan rabel untuk degree of freedom $(\mathrm{df})=\mathrm{n}-2$, $\mathrm{n}$ adalah jumlah sampel, jika rhitung $>$ rtabel dan nilai positif maka butir atau pertanyaan atau indikator tersebut dinyatakan valid (Ghozali, 2018).

Tabel 1. Hasil Uji Validitas

\begin{tabular}{|c|c|c|c|c|c|}
\hline Variabel & Item & $\mathbf{r}_{\text {hitung }}$ & $\mathbf{r}_{\text {tabel }}$ & Sign & Keterangan \\
\hline \multirow{11}{*}{$\begin{array}{c}\text { Perilaku } \\
\text { Konsumtif }(X 1)\end{array}$} & $X 1.1$ & 0,554 & 0,1690 & 0,000 & Valid \\
\hline & $X 1.2$ & 0,740 & 0,1690 & 0,000 & Valid \\
\hline & $X 1.3$ & 0,581 & 0,1690 & 0,000 & Valid \\
\hline & $X 1.4$ & 0,581 & 0,1690 & 0,000 & Valid \\
\hline & $X 1.5$ & 0,551 & 0,1690 & 0,000 & Valid \\
\hline & $X 1.6$ & 0,530 & 0,1690 & 0,000 & Valid \\
\hline & $X 1.7$ & 0,649 & 0,1690 & 0,000 & Valid \\
\hline & $X 1.8$ & 0,714 & 0,1690 & 0,000 & Valid \\
\hline & $X 1.9$ & 0,674 & 0,1690 & 0,000 & Valid \\
\hline & $X 1.10$ & 0,510 & 0,1690 & 0,000 & Valid \\
\hline & $X 1.11$ & 0,629 & 0,1690 & 0,000 & Valid \\
\hline \multirow{5}{*}{ Motivasi (X2) } & $X 2.1$ & 0,694 & 0,1690 & 0,000 & Valid \\
\hline & $X 2.2$ & 0,696 & 0,1690 & 0,000 & Valid \\
\hline & $X 2.3$ & 0,644 & 0,1690 & 0,000 & Valid \\
\hline & $X 2.4$ & 0,553 & 0,1690 & 0,000 & Valid \\
\hline & $X 2.5$ & 0,505 & 0,1690 & 0,000 & Valid \\
\hline \multirow{7}{*}{$\begin{array}{c}\text { Kelompok } \\
\text { Referensi (X3) }\end{array}$} & $X 3.1$ & 0,648 & 0,1690 & 0,000 & Valid \\
\hline & $X 3.2$ & 0,678 & 0,1690 & 0,000 & Valid \\
\hline & $X 3.3$ & 0722 & 0,1690 & 0,000 & Valid \\
\hline & $X 3.4$ & 0,707 & 0,1690 & 0,000 & Valid \\
\hline & $X 3.5$ & 0,720 & 0,1690 & 0,000 & Valid \\
\hline & $X 3.6$ & 0,709 & 0,1690 & 0,000 & Valid \\
\hline & $X 4.1$ & 0,686 & 0,1690 & 0,000 & Valid \\
\hline \multirow{4}{*}{$\begin{array}{c}\text { Kualitas } \\
\text { Layanan (X4) }\end{array}$} & $X 4.2$ & 0,762 & 0,1690 & 0,000 & Valid \\
\hline & $X 4.3$ & 0,783 & 0,1690 & 0,000 & Valid \\
\hline & $X 4.4$ & 0,825 & 0,1690 & 0,000 & Valid \\
\hline & $X 4.5$ & 0,769 & 0,1690 & 0,000 & Valid \\
\hline
\end{tabular}




\begin{tabular}{llllll} 
& $X 4.6$ & 0,834 & 0,1690 & 0,000 & Valid \\
& $X 4.7$ & 0,814 & 0,1690 & 0,000 & Valid \\
\hline \multirow{4}{*}{ Keputusan } & $Y 1.1$ & 0,773 & 0,1690 & 0,000 & Valid \\
Menabung $(Y)$ & $Y 1.2$ & 0,797 & 0,1690 & 0,000 & Valid \\
& $Y 1.4$ & 0,720 & 0,1690 & 0,000 & Valid \\
& $Y 1.5$ & 0,696 & 0,1690 & 0,000 & Valid \\
& & 0,722 & 0,1690 & 0,000 & Valid \\
\hline
\end{tabular}

Sumber : Data primer diolah, 2020.

Berdasarkan Tabel 1. dapat diketahui bahwa hasil pengujian validitas menunjukkan keseluruhan indikator variabel perilaku konsumtif, motivasi, kelompok referensi, kualitas layanan dan keputusan menabung adalah valid. Hal ini dikarenakan keseluruhan indikator memiliki nilai rhitung yang melebihi nilai rtabel, atau nilai signifikansi sebesar $0,000<0,05$.

\section{Uji Reliabilitas}

Uji reliabilitas adalah alat untuk mengukur suatu kuesioner yang merupakan indikator dari variabel atau konstruk. Untuk mengukur reliabilitas dengan melihat Cronbach's Alpha. Suatu konstruk atau variabel dapat dikatakan reliabel jika memberikan nilai Cronbach's Alpha masing-masing variabel lebih dari 60\% atau 0,6 maka penelitian ini dikatakan reliabel (Asnawi dan Masyhuri, 2009).

Tabel 2. Hasil Uji Reliabilitas

\begin{tabular}{llll}
\hline \multicolumn{1}{c}{ Variabel dan Indikator } & \multicolumn{1}{c}{$\begin{array}{c}\text { Hasil Cronbach's } \\
\text { Alpha }\end{array}$} & $\begin{array}{c}\text { Standar } \\
\text { Minimum }\end{array}$ & Keterangan \\
\hline Perilaku Konsumtif & 0,832 & 0,60 & Reliabel \\
Motivasi & 0,603 & 0,60 & Reliabel \\
Kelompok Referensi & 0,781 & 0,60 & Reliabel \\
Kualitas Layanan & 0,886 & 0,60 & Reliabel \\
Keputusan Menabung & 0,792 & 0,60 & Reliabel \\
\hline
\end{tabular}

Sumber : Data primer diolah, 2020.

Berdasarkan Tabel 2. terlihat bahwa nilai Cronbach's Alpha $>0,60$ atau $60 \%$. Jadi dapat disimpulkan bahwa tiap-tiap pertanyaan dari semua variabel perilaku konsumtif, motivasi, kelompok referensi, kualitas layanan terhadap keputusan menabung adalah reliabel.

\section{Uji Normalitas}

Menurut Ghozali (2018) uji normalitas bertujuan untuk menguji apakah dalam model regresi, variabel pengganggu atau residual memiliki distribusi normal. Dalam penelitian ini untuk menguji normalitas sebuah model regresi menggunakan 2 (dua) cara analisis, yaitu analisis grafik (histogram dan P-Plot) serta analisis statistik (non-parametik Kolmogorov-Smirnov). Hasil uji normalitas dengan menggunakan analisis grafik dapat dilihat pada Gambar 1 dan Gambar 2 juga dengan analisis statistik pada Tabel 3. 
Gambar 1. Hasil Normalitas Grafik Histogram

Histogram

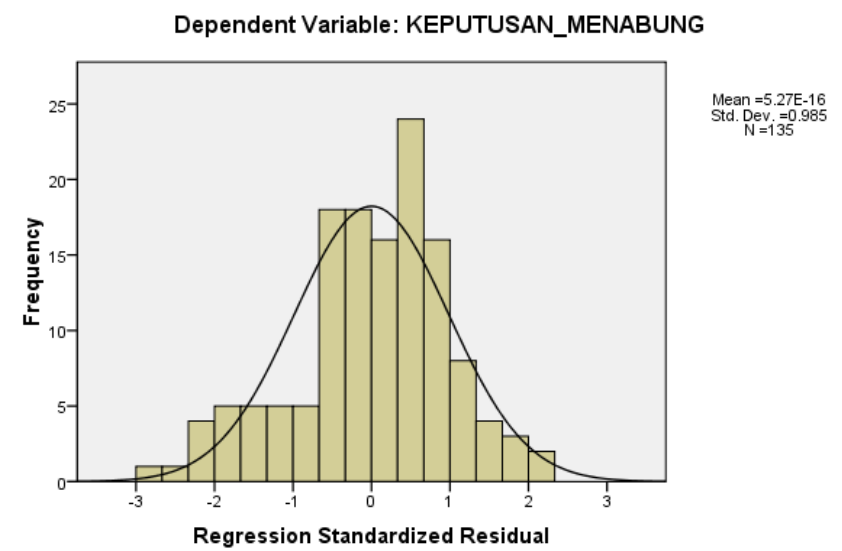

Sumber : Data primer diolah, 2020.

Gambar 2. Hasil Normalitas P-Plot

Normal P-P Plot of Regression Standardized Residual
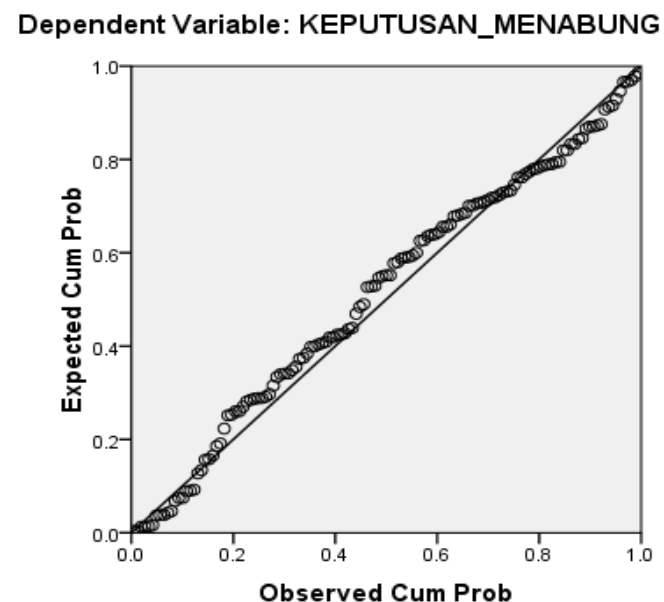

Sumber: Data primer diolah, 2020.

Berdasarkan Gambar 1 terlihat grafik histogram memberikan pola distribusi yang melenceng atau condong ke kanan yang artinya data dalam penelitian ini berdistribusi normal. Sedangkan pada Gambar 2 juga terlihat titik-titik mengikuti dan mendekati garis diagonalnya sehingga dapat disimpulkan data dalam penelitian ini berdistribusi normal. 
Tabel 4.3. Hasil Uji Kolmogorov Smirnov $(K-S)$

One-Sample Kolmogorov-Smirnov Test

\begin{tabular}{lll}
\hline & & $\begin{array}{l}\text { Unstandardize } \\
\text { d Residual }\end{array}$ \\
$N$ & & 135 \\
Normal Parameters $^{a}$ & Mean & .0000000 \\
& Std. Deviation & 2.11243052 \\
Most Extreme Differences & Absolute & .068 \\
& Positive & .047 \\
& Negative & -.068 \\
Kolmogorov-Smirnov Z & & .786 \\
Asymp. Sig. (2-tailed) & & .568 \\
\hline
\end{tabular}

a. Test distribution is Normal.

Sumber:Data primer diolah, 2020.

Berdasarkan Tabel 3. dari hasil Uji Statistik Non-Parametik KolomogorovSmirnov (K-S) diketahui bahwa nilai signifikansi sebesar 0,568 lebih besar dari 0,05. Hal ini menunjukkan bahwa data dalam penelitian ini berdistribusi normal.

\section{Uji Multikolonieritas}

Bertujuan untuk menguji apakah model regresi ditemukan adanya korelasi antar variabel bebas (independen). Untuk menguji ada tidaknya multikolonieritas dapat diketahui dari besarnya nilai tolerance dan VIF (Variance Inflation Factor). Nilai cut off yang umum digunakan untuk menunjukkan adanya multikolonieritas adalah nilai tolerance $\leq 0,10$ atau sama dengan nilai VIF $\geq 10$ (Ghozali,2018:107-108). Hasil uji multikolonieritas dapat dilihat pada Tabel 4.

Tabel 4. Hasil Uji Multikolonieritas

\begin{tabular}{llll}
\hline \multicolumn{3}{c}{ Coefficients $^{a}$} \\
\hline \multirow{3}{*}{ Model } & & \multicolumn{2}{c}{ Collinearity Statistics } \\
1 & & Tolerance & VIF \\
& Perilaku_Konsumtif & .781 & 1.280 \\
& Motivasi & .770 & 1.298 \\
& Kelompok_Referensi & .671 & 1.491 \\
& Kualitas_Layanan & .729 & 1.371 \\
\hline
\end{tabular}

a. Dependent Variable: Keputusan_Menabung 
Berdasarkan Tabel 4. dapat dilihat bahwa nilai Tolerance memiliki nilai lebih dari 0,10 , dan nilai VIF kurang dari 10. Dengan demikian tidak adanya multikolonieritas antar variabel independen dalam model regresi.

\section{Uji Heteroskedastisitas}

Bertujuan menguji apakah dalam sebuah model regresi terjadi ketidaksamaan varian residual satu pengamatan ke pengamatan yang lain. Hasil Uji Glejser yang dapat dilihat pada Tabel 5.

Tabel 5. Hasil Uji Heteroskedastisitas

\begin{tabular}{|c|c|c|c|c|c|c|}
\hline \multicolumn{7}{|c|}{ Coefficients $^{a}$} \\
\hline & & \multirow{2}{*}{\multicolumn{2}{|c|}{$\begin{array}{l}\text { Unstandardized } \\
\text { Coefficients }\end{array}$}} & \multirow{2}{*}{\multicolumn{3}{|c|}{$\begin{array}{l}\text { Standardized } \\
\text { Coefficients }\end{array}$}} \\
\hline & & & & & & \\
\hline \multicolumn{2}{|c|}{ Model } & $B$ & Std. Error & Beta & $t$ & Sig. \\
\hline 1 & (Constant) & 2.540 & .980 & & 2.592 & .011 \\
\hline & Perilaku_Konsumtif & -.007 & .018 & -.035 & -.359 & .720 \\
\hline & Motivasi & -.055 & .041 & -.133 & -1.349 & .180 \\
\hline & Kelompok_Referensi & -.011 & .037 & -.031 & -.297 & .767 \\
\hline & Kualitas_Layanan & .020 & .034 & .058 & .574 & .567 \\
\hline
\end{tabular}

a. Dependent Variable: Abs_Res

Sumber: Data primer diolah, 2020.

Berdasarkan Tabel 5. menunjukkan bahwa signifikansi semua variabel independen tidak signifikan secara statistik atau signifikansi lebih besar dari 0,05. Maka dari itu dapat disimpulkan bahwa model regresi terbebas dari gejala heteroskedastisitas.

\section{Analisis Data}

Hasil analisisregresi linier berganda dapat dilinb hat pada Tabel 6.

Tabel 6. Hasil Analisis Regresi Linier Berganda

\begin{tabular}{llll}
\hline & & \multicolumn{2}{l}{$\begin{array}{l}\text { Unstandardized } \\
\text { Coefficients }\end{array}$} \\
& & $B$ & Std. Error \\
\hline 1 & (Constant) & 4.047 & 1.632 \\
& Perilaku_Konsumtif & -.032 & .030 \\
& Motivasi & .315 & .068 \\
& Kelompok_Referensi & .103 & .062 \\
& Kualitas_Layanan & .325 & .057 \\
\hline
\end{tabular}

a. Dependent Variable: Keputusan_Menabung 
Berdasarkan Tabel 6. dapat dijabarkan dalam persamaan regresi linier berganda sebagai berikut:

Keputusan Menabung = 4,047 - 0,032 Perilaku Konsumtif + 0,315 Motivasi + 0,103 Kelompok Referensi + 0,325 Kualitas Layanan

\section{Pengujian Hipotesis}

Pengujian hipotesis dalam penelitian ini menggunakan uji statistik F, Uji koefisien determinasi $\left(R^{2}\right)$, dan uji statistik t.

\section{Uji Statistik F}

Ftabel dalam penelitian ini adalah sebesar 2,44 dan besarnya $\alpha$ yang ditentukan adalah 0,05 atau $5 \%$. Adapun hasil Uji statistik F dari hasil analisis data dalam penelitian ini dapat dilihat pada Tabel 7.

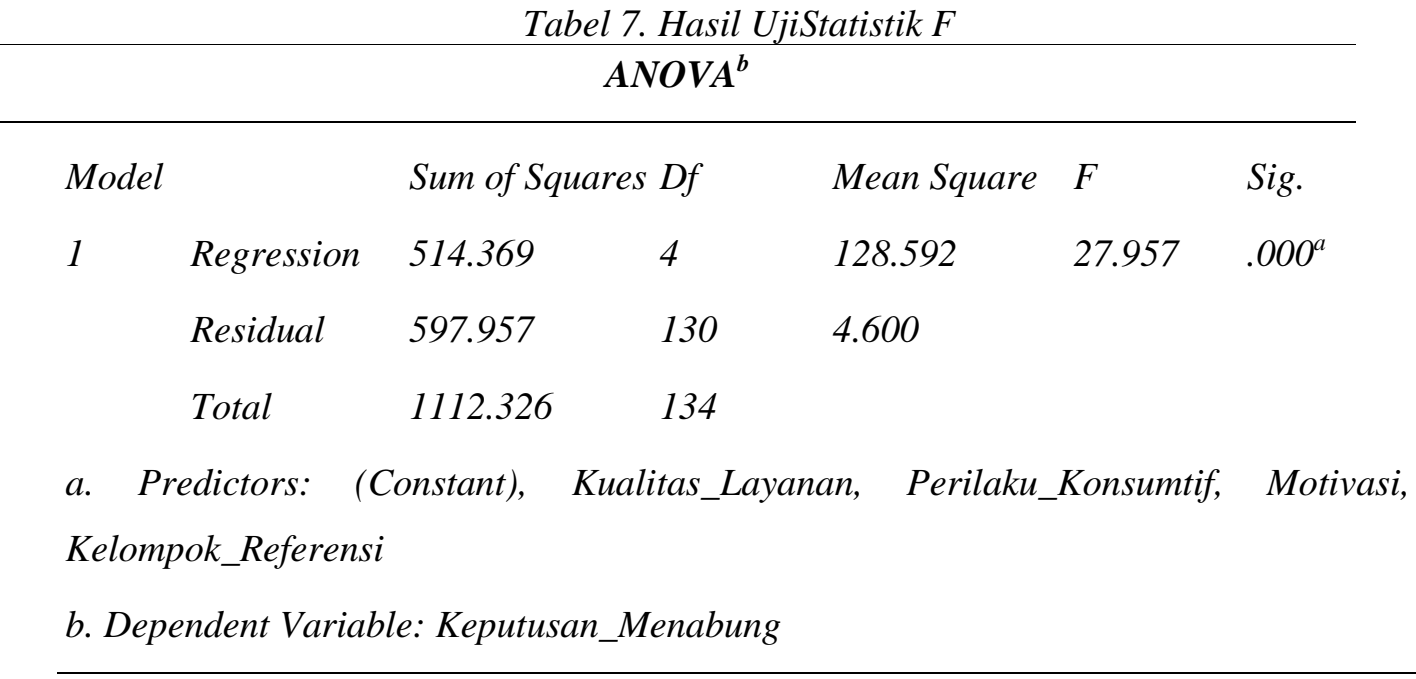

Sumber: Data primer diolah, 2020

Berdasarkan Tabel 7.dihasilkan Fhitung $=27,957>F_{\text {tabel }}=2,44$ atau signifikansi $=$ $0,000<0,05$ yang berarti terdapat pengaruh yang signifikan antara variabel perilaku konsumtif, motivasi, kelompok referensi dan kualitas layanan secara simultan terhadap keputusan menabung.

\section{Hasil Pengujian Koefesien Determinasi $\left(R^{2}\right)$}

Hasil uji koefisien determinasi $\left(R^{2}\right)$ dalam penelitian ini dilakukan untuk mengukur seberapa jauh kemampuan model dalam menerangkan variasi variabel dependen. Hasil Uji koefisien determinasi $\left(R^{2}\right)$ dapat dilihat pada Tabel 8. 
Tabel 8. Hasil Uji Koefisien Determinasi $\left(\boldsymbol{R}^{2}\right)$

\section{Model Summary ${ }^{b}$}

$\begin{array}{llllc}\text { Model } R & R \text { Square } & \text { Adjusted R Square } & \text { Std. Error of the Estimate } \\ 1 & .680^{a} & .462 & .446 & 2.145 \\ \text { a. } & \text { Predictors: } & \text { (Constant), } & \text { Kualitas_Layanan, } & \text { Perilaku_Konsumtif, }\end{array}$

Kelompok_Referensi

b. Dependent Variable: Keputusan_Menabung

Sumber: Data primer diolah, 2020.

Berdasarkan hasil uji koefisien determinasi pada Tabel 8. dihasilkan nilai Adjusted $\mathrm{R}$ Square sebesar 0,446 atau 44,60 \% artinya variabel perilaku konsumtif, motivasi, kelompok referensi dan kualitas layanan memberikan kontribusi pengaruh terhadap keputusan menabung sebesar 44,60 \%. Sedangkan sisanya sebesar 55,40 \% dipengaruhi oleh variabel lain yang tidak diteliti dalam penelitian ini.

\section{Uji Statistik $t$}

Bertujuan untuk mengetahui besarnya pengaruh masing-masingvariabel independen secara parsial terhadap variabel dependen. $t$ tabel dalam penelitian ini sebesar 1,983 dan besarnya $\alpha$ yang ditentukan adalah $5 \%$.Hasil Uji statistik $\mathrm{t}$ dari hasil analisis data dalam penelitian ini dapat dilihat pada Tabel 9.

\section{Tabel 9. Hasil Uji Statistik $t$}

\begin{tabular}{|c|c|c|c|c|c|c|}
\hline \multicolumn{7}{|c|}{ Coefficients $^{a}$} \\
\hline \multirow[b]{3}{*}{ Model } & & \multicolumn{2}{|c|}{ Unstandardized } & \multicolumn{3}{|l|}{ Standardized } \\
\hline & & \multicolumn{2}{|c|}{ Coefficients } & Coefficients & & \\
\hline & & $B$ & Std. Error & Beta & $t$ & Sig. \\
\hline 1 & (Constant) & 4.047 & 1.632 & & 2.479 & .014 \\
\hline & Perilaku_Konsumtif & -.032 & .030 & -.078 & -1.068 & .288 \\
\hline & Motivasi & .315 & .068 & .340 & 4.645 & .000 \\
\hline & Kelompok_Referensi & .103 & .062 & .130 & 1.658 & .100 \\
\hline & Kualitas_Layanan & .325 & .057 & .429 & 5.701 & .000 \\
\hline
\end{tabular}

a. Dependent Variable: Keputusan_Menabung

Sumber: Data primer diolah, 2020.

Berdasarkan Tabel 9 hasil uji statistik t dapat dilakukan pembuktian hipotesis terhadap masing-masing variabel sebagai berikut:

\section{Pembuktian Hipotesis 2}

Pembuktian hipotesis 2 (dua) dilakukan dengan uji statistik t. Berdasarkan Tabel 4.16. dihasilkan thitung untuk variabel perilaku konsumtif $=-1,068<\mathrm{t}$ tabel $=1,978$ atau 
signifikansi $=0,288>0,05$ yang berarti tidak terdapat pengaruh yang signifikan antara perilaku konsumtif secara parsial terhadap keputusan menabung.

\section{Pembuktian Hipotesis 3}

Pembuktian hipotesis 3 (tiga) dilakukan dengan uji statistik t. Berdasarkan Tabel 4.16. dihasilkan $\mathrm{t}$ hitung untuk variabel motivasi $=4,645>\mathrm{t}$ tabel $=1,978$ atau signifikansi $=0,000<0,05$ yang berarti terdapat pengaruh yang signifikan antara motivasi secara parsial terhadap keputusan menabung.

\section{Pembuktian Hipotesis 4}

Pembuktian hipotesis 4 (empat) dilakukan dengan uji statistik t. Berdasarkan Tabel 4.16. dihasilkan $\mathrm{t}$ hitung untuk variabel kelompok referensi $=1,658<\mathrm{t}$ tabel $=$ 1,978 atau signifikansi $=0,100>0,05$ yang berarti tidak terdapat pengaruh yang signifikan antara kelompok referensi secara parsial terhadap keputusan menabung.

\section{Pembuktian Hipotesis 5}

Pembuktian hipotesis 5 (lima) dilakukan dengan uji statistik t. Berdasarkan Tabel 4.16. dihasilkan $\mathrm{t}$ hitung untuk variabel kualitas layanan $=5,701>\mathrm{t}$ tabel $=1,978$ atau signifikansi $=0,000<0,05$ yang berarti terdapat pengaruh yang signifikan antara kualitas layanan secara parsial terhadap keputusan menabung.

\section{Pembahasan Hipotesis 1}

Berdasarkan pembuktian hipotesis 1 (satu) dinyatakan bahwa variabel perilaku konsumtif, motivasi, kelompok referensi dan kualitas layanan secara simultan berpengaruh signifikan terhadap keputusan menabung pada PT Bank Tabungan Negara (BTN) Kantor Cabang Syariah Semarang. Hal ini menunjukkan bahwa penggabungan variabel perilaku konsumtif, motivasi, kelompok referensi dan kualitas layanan layak untukdijadikan alat prediksi untuk mengendalikan keputusan menabung pada PT Bank Tabungan Negara (BTN) Kantor Cabang Syariah Semarang.

Berdasarkan hasil uji koefisien determinasi menunjukkan nilai Adjusted R Square sebesar 0,446 atau 44,60 \%. Hal ini menunjukkan bahwa variabel perilaku konsumtif, motivasi, kelompok referensi dan kualitas layananmemberikan kontribusi pengaruh terhadap keputusan menabung sebesar 44,60 \%. Sedangkan 55,40 \% sisanya dipengaruhi oleh variabel lain yang tidak diteliti dalam penelitian ini.

Insukindro (1999) menyatakan bahwa koefisien determinasi hanyalah salah satu dan bukan satu-satunya kriteria memilih model yang baik. Alasannya bila suatu estimasi regresi linear menghasilkan koefisien determinasi yang tinggi, tetapi tidak konsisten dengan teori ekonomika yang dipilih oleh peneliti, atau tidak lolos dari uji asumsi klasik, maka model tersebut bukanlah model penaksir yang baik dan seharusnya tidak dipilih menjadi model empiris.

Kemudian Gujarati dan Porter (2010:266) juga menyatakan bahwa dalam analisis empiris tidak penting untuk mendapatkan nilai $R^{2}$ yang tinggi, tetapi sebenarnya untuk mengetahui apakah koefisien regresi memiliki pengaruh signifikan atau menunjukkan bahwa koefisien berbeda dengan ekspektasi atau harapan sebelumnya. Ketika model mendapat nilai $R^{2}$ yang tinggi, hal tersebut menunjukkan model yang baik. Namun bila nilai $R^{2}$ rendah, tidak berarti bahwa model regresi jelek. 


\section{Pembahasan Hipotesis 2}

Berdasarkan pembuktian hipotesis 2 (dua) menyatakan bahwa variabel perilaku konsumtif secara parsial tidak berpengaruh signifikan terhadap keputusan menabung pada PT Bank Tabungan Negara (BTN) Kantor Cabang Syariah Semarang.

Semula diduga perilaku konsumtif secara parsial berpengaruh signifikan terhadap keputusan menabung. Hal ini didukung oleh pandangan yang dikemukakan Putong (2003:186) yang menyatakan bahwa semua pendapatan masyarakat yang tidak dikonsumsi itu ditabung dan atau dipergunakan untuk investasi. Dengan demikian apabila konsumsi yang dibutuhkan sudah tercukupi maka besar kemungkinan sisa pendapatan tersebut dialokasikan untuk tabungan dan atau investasi. Hal ini juga didukung oleh pandangan Sirine dan Utami (2016) yang menyatakan bahwa penentu penting lain dari perilaku konsumtif yaitu perilaku menabung dan pengeluaran individu, dimana adanya kontrol diri. Apabila kontrol diri seseorang tersebut positif atau mampu mengontrol keinginan dirinya sendiri untuk tidak mengonsumsi barang secara berlebihan, hal tersebut dapat memengaruhi perilaku hemat, yang nantinya juga berdampak pada tingkat pengeluaran kebutuhan dan perilaku menabung. Dengan demikian perilaku konsumtif seseorang lebih terkontrol (Esenvalde, 2011) dalam (Sirine dan Utami, 2016).

Namun, hasil penelitian ini menunjukkan bahwa perilaku konsumtif secara parsial tidak berpengaruh signifikanterhadap keputusan menabung. Hal Ini berarti peningkatan atau penurunan konsumsi nasabah tidak memiliki hubungan yang signifikan dengan keputusan menabung nasabah.

Hasil penelitian ini kontradiksi dengan penelitian terdahulu yang dilakukan oleh Rahmani (2019) dan Pramudi (2015) yang menyatakan bahwa perilaku konsumtif secara parsial berpengaruh signifikan terhadap keputusan pembelian atau dalam penelitian ini keputusan menabung. Namun, sejalan dengan penelitian yang dilakukan oleh Ardianto (2017) menyatakan perilaku konsumtif secara parsial tidak berpengaruh signifikan terhadap keputusan pembelian atau dalam penelitian keputusan menabung dan Widiatmoko, et al., (2013) yang menyatakan gaya hidup secara parsial tidak berpengaruh signifikan terhadap keputusan menabung dan dalam penelitian ini perilaku konsumtif merupakan bagian dari gaya hidup.

\section{Pembahasan Hipotesis 3}

Berdasarkan pembuktian hipotesis 3 (tiga) menyatakan bahwa variabel motivasi secara parsial berpengaruh signifikan terhadap keputusan menabung pada PT Bank Tabungan Negara (BTN) Kantor Cabang Syariah Semarang.

Hal ini sejalan dengan pandangan yang dikemukakan Kotler (2012) bahwa terdapat beberapa faktor yang dapat memengaruhi perilaku pembelian konsumen. Salah satu faktornya adalah motivasi atau dari faktor psikologis. Hasil yang diperoleh dapat mengindikasikan bahwa motivasi berperan penting didalam menentukan keputusan pembelian atau dalam penelitian ini keputusan menabung. Dengan adanya pengaruh yang diberikan, maka bank syariah tentu perlu memperhatikan aspek-aspek dari motivasi untuk dapat meningkatkan motivasi nasabah untuk menabung di bank syariah.

Hal ini jsejalan dengan pandangan yang dikemukakan Mayasari,et al., (2017) yang menyatakan bahwa semakin baiknya motivasi nasabah berakibat pada meningkatnya keputusan nasabah untuk menabung di bank syariah. Kaunang, et al., (2015) juga menyatakan bahwa seseorang akan termotivasi untuk melakukan pembelian jika ada 
dorongan. Semakin kuatdorongan yang diberikan maka seseorang akan semakin termotivasi untuk melakukan keputusanpembelian. Motivasi yang tinggi dari konsumen akan menarik minat konsumen untuk melakukan keputusan pembelian atau dalam penelitian ini keputusan menabung.

Hasil penelitian ini mendukung penelitian terdahulu yang dilakukan oleh Mandali,et al., (2016), Septianan dan Indrajaya (2018), Mayasari,et al., (2017) dan Utami,et al., (2015) yang menyatakan bahwa motivasi secara parsial berpengaruh signifikan terhadap keputusan menabung pada bank syariah.

\section{Pembahasan Hipotesis 4}

Berdasarkan pembuktian hipotesis 4 (empat) menyatakan bahwa variabel kelompok referensi secara parsial tidak berpengaruh signifikan terhadap keputusan menabung pada PT Bank Tabungan Negara (BTN) Kantor Cabang Syariah Semarang.

Semula diduga kelompok referensi secara parsial berpengaruh signifikan terhadap keputusan menabung. Hal ini didasari oleh pandangan yang dikemukakan Kotler (1990:112) yang menyatakan bahwa adanya pengaruh dalam pengambilan keputusan konsumen dipengaruhi dari faktor sosial seperti kelompok referensi. Sumber paling efektif berasal dari berbagai sumber pribadi (kelompok primer) seperti keluarga, kawan, tetangga, kolega dan lain sebagainya. Dengan demikian pengaruh kelompok cenderung lebih kuat dan besar kemungkinan sebelum membeli produk yang akan dibelinya, seseorang tersebut cenderung akan berusaha mencari lebih banyak informasi mengenai produk tersebut.

Namun, hasil menunjukkan kelompok referensi secara parsial tidak berpengaruh signifikanterhadap keputusan menabung. Hal ini berarti berbagai informasi yang didapatkan oleh nasabah dari kelompok acuan tidak memiliki hubungan yang signifikan terhadap keputusan menabung nasabah.

Hasil penelitian ini kontradiksi dengan penelitian terdahulu yang dilakukan oleh Utami, et al., (2015), Kartikasari dan Endratno (2016) dan Wina, et al., (2015) yang menyatakan bahwa kelompok referensi berpengaruh signifikan terhadap keputusan nasabah dalam menabung di bank syariah. Namun, sejalan denganpenelitian Faadhilah (2018) yang menyatakan bahwa kelompok referensi tidak berpengaruh signifikan terhadap keputusan pembelian.

\section{Pembahasan Hipotesis 5}

Berdasarkan pembuktian hipotesis 5 (lima) menyatakan bahwa variabel kualitas layanan secara parsial berpengaruh signifikan terhadap keputusan menabung pada PT Bank Tabungan Negara (BTN) Kantor Cabang Syariah Semarang.

Hal ini sejalan dengan pandangan yang dikemukakan oleh Arslan (2014) bahwa dengan kualitas pelayanan yang baik mampu meningkatkan kunjungan konsumen pada toko atau perusahaan dan juga meningkatkan keputusan pembelian pada konsumen. Ketika sebuah toko atau perusahaan menyediakan pelayanan yang optimal pada konsumen, maka keputusan pembelian produk dan kepuasaan konsumen terhadap barang atau jasa yang dijual tersebut akan timbul dengan sendirinya atau dalam hal ini berdampak terhadap keputusan menabung nasabah secara berkala.

Hasil penelitian ini mendukung penelitian terdahulu yang dilakukan oleh Mayasari,et al., (2017), Arifin dan Khotimah (2014), Fahrudin dan Yulianti (2015) dan 
Haris dan Irham (2012) yang menyatakan bahwa kualitas layanan berpengaruh signifikan terhadap keputusan menabung.

\section{KESIMPULAN}

Berdasarkan hasil analisis dan pembahasan yang telah dilakukan dalam penelitian ini mengenai analisis pengaruh variabel perilaku konsumtif, motivasi, kelompok referensi dan kualitas layanan terhadap keputusan menabung pada PT Bank Tabungan Negara (BTN) Kantor Cabang Syariah Semarang, dapat diambil kesimpulan bahwa perilaku konsumtif, motivasi, kelompok referensi dan kualitas layanan secara simultan berpengaruh signifikan terhadap keputusan menabung pada PT Bank Tabungan Negara (BTN) Kantor Cabang Syariah Semarang. Secara parsial motivasi dan kualitas layanan berpengaruh signifikan terhadap keputusan menabung pada PT Bank Tabungan Negara (BTN) Kantor Cabang Syariah Semarang. Sedangkan perilaku konsumtif dan kelompok referensi secara parsial tidak berpengaruh signifikan terhadap keputusan menabung pada PT Bank Tabungan Negara (BTN) Kantor Cabang Syariah Semarang.

\section{REFERENSI}

Ardianto, Agustinus Kristian. 2017. Moderasi Gaya Hidup Konsumtif dalam Pengaruh Diskon Terhadap Keputusan Pembelian. Skripsi. Yogyakarta.

Arifin, Atwal dan Husnul Khotimah. 2014. Pengaruh Produk, Pelayanan, Promosi Dan Lokasi Terhadap Keputusan Masyarakat Memilih Bank Syariah Di Surakarta. Seminar Nasional Dan Call For Paper.

Arslan, Muhammad dan Zaman, Rashid. 2014. Impact of Brand Image and Service Quality on Consumer Purchase Intention: A Study of Retail Store in Pakistan. Research on Humanities and Social Sciences. Vol. 4, No. 22. ISSN. 2224-5766.

Asnawi dan Masyhuri. 2009. Metodologi Riset Manajemen Pemasaran. Malang: UIN Malang-Malang Press.

BTN. 2018. “Tentang Kami”. https://www.btn.co.id/Tentang- Kami.(05 Mei 2020)

Faadhilah, Fauz Novia. 2018. Pengaruh Gaya Hidup Konsumtif dan Beauty Vlogger Sebagai Kelompok Referensi Terhadap Keputusan Pembelian Kosmetik (Studi Pada Remaja Perempuan Pengguna Kosmetik Korea Di Surabaya). Jurnal Ilmu Manajemen. Vol. 7, No. 1.

Fahrudin, Muhammad Fajar dan Emma Yulianti. 2015. Pengaruh promosi, lokasi,dan kualitas layanan terhadap keputusan pembelian nasabah Bank Mandiri Surabaya. Journal of Business and Banking. Vol. 5, No. 1.

Ferdinand, Augusty. 2014. Metode Penelitian Manajemen. Semarang: Badan Penerbit Undip.

Ferdinand, Augusty. 2006. Metode Penelitian Manajemen. Semarang: Badan Penerbit Undip.

Ghozali, Imam. 2018. Aplikasi Analisis Multivariate dengan Program SPSS. Semarang : Badan Penerbit Universitas Diponegoro. 
Hanik, Siti Umi dan Jati Handayani. 2014. Keputusan Nasabah Dalam Memilih Perbankan Syariah (Studi Kasus Pada Nasabah Bank Syariah Mandiri). Jurnal JABPI. Vol. 22, No. 2.

Haris, Helmi dan Nur Said Irham T. 2012. Pengaruh Kualitas Pelayanan dan Periklanan terhadap Keputusan Nasabah dalam Menabung pada Bank Syariah (Studi Kasus pada BTN Syariah Surakarta). Jurnal Muqtasid. Vol. 3, No. 1.

Insukindro. 1998. Sindrum $R^{2}$ Dalam Analisis Regresi Linier Berganda Runtun Waktu. Jurnal Ekonomi dan Bisnis Indonesia. Vol. 13, No. 4.

Kartikasari, Nita Despri dan Hermin Endratno. 2016. Analisis Faktor-Faktor Yang Mempengaruhi Keputusan Nasabah Untuk Menyimpan Dana Pada Bank Syari'ah Di Kota Purwokerto (Studi Pada Bri Syariah Dan Bank Muammalat Cabang Purwokerto). Jurnal Manajemen dan Bisnis Media Ekonomi.Vol. 16, No. 2.

Kaunang, Meiriska. 2015. Analisis Pengaruh Motivasi, Konsumen, Persepsi, Kualitas Layanan dan Promosi Terhadap Keputusan Pembelian Sepeda Motor di Kota Manado. Jurnal Berkala Ilmiah Efisiensi. Vol. 15, No.5.

Kotler, Philip dan Kevin Lane Keller. 2012. Marketing Management. England: Pearson Education Limited.

Kristianto, Paulus Lilik. 2011. Psikologi Pemasaran. Jakarta: PT. Buku Seru.

Mandali, Ronaldo, Rahmiati dan Hendri Andi Mesta. 2016. Pengaruh Faktor Psikologis Terhadap Keputusan Menabung Mahasiswa Pada Bank Syariah. Jurnal Kajian Manajemen Bisnis. Vol. 5,No. 1.

Sugiyono.2014. Metode Penelitian Kuantitatif, Kualitatif dan R\&D. Bandung: PT Alfabet.

Sulistyorini, Utami Tri. 2017. Metode Penelitian Analisis Kausal-Regresi. Semarang: Polines.

Utami, Sangen dan Rahman. 2015. Analisis Pengaruh Religiusitas, Kelompok Referensi dan Motivasi terhadap Keputusan Menabung di Bank Syariah. Jurnal Wawasan Manajemen. Vol. 3, No.1.

Widiatmoko, Brono, Darwin Sitompul dan Sukaria Sinulingga. 2013. Faktor-Faktor Yang Mempengaruhi Keputusan NasabahMembuka Rekening Tahapan Xpresi Pada Bca Medan.Jurnal Ekonomi Manajemen Sumber Daya. Vol. 14, No. 2.

Wina, elsa, Nawazirul Lubiz dan Bulan Prabawani. 2015. Pengaruh Promosi dan Kelompok Referensi terhadap Keputusan Menabung Nasabah Tabungan Simpedes pada PT. Bank Rakyat Indonesia (Persero) Tbk Kantor Cabang Brigjen Sudiarto Semarang. Jurnal jurusan Administrasi Bisnis. Diunduh pada 20 Desember 2019.

www.bps.go.id (diakses pada Mei 2020).

www.ojk.go.id (diakses pada Januari 2020).

Zainal, Veithzal Rivai. 2018. Ekonomi Mikro Islam. Jakarta Pusat: Bumi Aksara. 